\title{
The effectiveness of gentamicin in the treatment of Neisseria gonorrhoeae: a systematic review
}

\author{
Emma Hathorn ${ }^{1 *}$, Divya Dhasmana', Lelia Duley ${ }^{2}$ and Jonathan DC Ross ${ }^{1}$
}

\begin{abstract}
Background: A high level of resistance in Neisseria gonorrhoeae has developed against penicillins, sulphonamides, tetracyclines and quinolones, and recent surveillance data have shown a gradual reduction in sensitivity to current first-line agents with an upward drift in the minimum inhibitory concentration of ceftriaxone. Laboratory sensitivity testing suggests that gentamicin, an aminoglycoside, may be an effective treatment option for gonorrhoea infection when used as a single intramuscular dose.

Methods: A search of electronic reference databases and grey literature was used to identify randomised trials and well-conducted prospective studies with concurrent controls evaluating single-dose gentamicin against placebo or a comparator regimen in the treatment of uncomplicated gonorrhoea infection in men and women aged 16 years and over. The primary outcome was microbiological cure of $\mathrm{N}$. gonorrhoeae.

Results: Eight hundred and thirty-nine studies were identified, of which five (1,063 total participants) were included. All five studies administered single-dose gentamicin via intramuscular injection to men with uncomplicated gonococcal urethritis. Three studies were randomised trials, one was quasi-randomised and one was non-randomised but included a comparator arm. Comparator antibiotics included an alternative aminoglycoside or antibiotic used in the syndromic management of male urethritis. Methodology was poorly described in all five included studies. The high risk of bias within studies and clinical heterogeneity between studies meant that it was inappropriate to pool data for meta-analysis. Cure rates of $62 \%$ to $98 \%$ were reported with gentamicin treatment. The relative risk of cure was comparable between gentamicin and comparator antibiotics.
\end{abstract}

Conclusions: The studies identified provide insufficient data to support or refute the efficacy and safety of single-dose intramuscular gentamicin in the treatment of uncomplicated gonorrhoea infection. Additional randomised trials to evaluate gentamicin for this indication are therefore required.

Systematic review registration: PROSPERO CRD42012002490

Keywords: Gonorrhoea, Neisseria gonorrhoeae, Gentamicin, Treatment

\section{Background}

Gonorrhoea, caused by Neisseria gonorrhoeae, is the second most common bacterial sexually transmitted infection in the UK. The number of gonorrhoea diagnoses continues to rise with latest data indicating a $52 \%$ increase in England from 16,835 to 25,525 infections between 2010 and 2012 [1]. The highest rates of infection are found in residents of urban areas, and infection is concentrated in core groups such as young people and

\footnotetext{
* Correspondence: emma.hathorn@nhs.net

${ }^{1}$ Whittall Street Clinic, University Hospitals Birmingham, Birmingham B6 4DH, UK

Full list of author information is available at the end of the article
}

men who have sex with men (MSM). Of male diagnoses in 2012, 42\% were reported in MSM and 55\% of heterosexual diagnoses were in those aged 15 to 24 years [1]. A number of factors, in addition to continuing levels of unsafe sexual behaviour, may have contributed to the observed increase in diagnosis of gonorrhoea including the introduction of highly sensitive nucleic acid amplification tests (NAATs), the introduction of self-testing including extra-genital sites (pharyngeal and rectal sites in MSM), an increase in sexual health screening following the roll-out of the National Chlamydia Screening Programme, and improvements in reporting and surveillance. However, the rise in incident infection reported 
in the UK mirrors the global trend; the World Health Organization (WHO) estimates gonorrhoea to represent 106.1 million of the 498.9 million new cases of curable sexually transmitted infections (syphilis, chlamydia, gonorrhoea and trichomoniasis) worldwide [2].

$N$. gonorrhoeae are intracellular gram-negative bacteria transmitted via sexual contact. They primarily infect the mucous membranes of the urethra, endocervix, rectum, pharynx and conjunctiva. Infection of the genital tract causes local inflammation that can result in dysuria, discharge, genital discomfort and pain. Infection in women may spread to the fallopian tubes and ovaries causing pelvic inflammatory disease (PID). Complications include infertility, chronic pelvic pain and ectopic pregnancy and can result in considerable physical and emotional morbidity in addition to a significant financial burden on healthcare services $[3,4]$. An estimate of the average lifetime costs for women who develop complications is $\$ 6,350$ for chronic pelvic pain, $\$ 6,840$ for ectopic pregnancy and $\$ 1,270$ for infertility [4].

Gonorrhoea has consistently been identified as a risk factor for incident HIV infection in both heterosexual and MSM populations [5-7]. This is thought to result from increased HIV viral shedding in genital secretions $[8,9]$ and from an increased concentration of target cells for HIV in the locally inflamed mucosa found in individuals with gonorrhoea [10]. Ensuring effective gonorrhoea testing and treatment is therefore important to both reduce the global incidence of curable sexually transmitted infections and control the spread of HIV.

Testing guidance advocates the use of NAATs to detect gonorrhoea [11-14]. These tests benefit from high sensitivity and specificity, quick turnaround times, ability to use non-invasive specimens from patients and permitting dual screening for chlamydia and gonorrhoea at extragenital sites. However, to allow antibiotic susceptibility testing, a sample for culture is also required. In vitro susceptibility testing is used to guide individual patient management in addition to providing data for surveillance programmes. Antibiotic resistance in N. gonorrhoeae is a continuing problem, and surveillance of antibiotic resistance with a change in empirical treatment when resistance occurs in $>5 \%$ of isolates is recommended [15]. This is of particular importance in resource-limited settings where testing for $N$. gonorrhoeae is difficult and individuals are typically treated using syndrome-based algorithms.

A high level of resistance in $N$. gonorrhoeae has developed against penicillins, sulphonamides, tetracyclines and fluoroquinolones, which are now no longer recommended for use. Current guidelines recommend a single dose of intramuscular ceftriaxone with or without the addition of a single oral dose of azithromycin for the treatment of uncomplicated gonorrhoea infection $[12,14,16,17]$. The European Centre for Disease
Prevention and Control (ECDC) has proposed a working case definition for confirmed treatment failure that includes both clinical and laboratory criteria [18]. The precise resistance breakpoint for cephalosporin antibiotics is unknown, but surveillance data from the gonococcal isolate surveillance projects in both the UK and US have reported an upward drift in the mean inhibitory concentration (MIC) of ceftriaxone (UK: 13\% with MIC over $0.03 \mathrm{mg} / \mathrm{l}$ in $2010 \mathrm{cf} .1 \%$ in 2007 [19]; US: $0.05 \%$ with MIC over $0.125 \mathrm{mcg} / \mathrm{ml}$ in $2006 \mathrm{cf} .0 .5 \%$ in 2010 [20]). Clinical failure of cephalosporins has now been reported in Japan and Europe [21-23].

The mechanism of resistance to cephalosporin antibiotics is not fully understood. Plasmid-mediated resistance has not been observed, but a number of chromosomal mechanisms, including the presence of mosaic pen $A$ genes and mutations in pen $A$, pen $B, m$ trR promoter and $m t r R$ genes, have been reported. Mosaicism of the pen $A$ gene that encodes penicillin-binding protein 2 (PBP2) is thought to be the predominant mechanism causing cephalosporin resistance. Penicillin-binding proteins are involved in the synthesis of peptidoglycan, a major component of bacterial cell walls. Mosaic sequences of PBP2, resulting from recombination events involving penA gene sequences from other Neisseria species, have been identified in clinical isolates that demonstrate reduced susceptibility to cefixime and ceftriaxone [24-26]. Options to treat gonorrhoea if cephalosporins become ineffective are severely limited.

Gentamicin, an aminoglycoside antibiotic, is known to be clinically effective in the treatment of gram-negative infections, exerting both a bacteriostatic and bactericidal effect. It is an inexpensive antibiotic and has been used successfully to treat genital gonorrhoea infections in resource-limited settings. Studies in Malawi have shown high susceptibility of gonococcal isolates to gentamicin in vivo and clinical cure rates of approximately $95 \%$ when used in combination with doxycycline $[27,28]$. Whilst it is not included in current UK or European gonorrhoea treatment guidelines, an evaluation of gentamicin susceptibility of gonorrhoea isolates across 17 European countries was performed in 2009 in response to the emergence of decreased susceptibility to third-generation, extendedspectrum cephalosporins. The majority of MICs for genital and rectal isolates fell within a narrow range: $95 \%$ of isolates within $4-8 \mathrm{mg} / \mathrm{l}$ and $79 \%$ of isolates demonstrating an MIC of $8 \mathrm{mg} / \mathrm{l}$ [29]. Cephalosporin-resistant gonococci are unlikely to exhibit cross-resistance to gentamicin given its bacteriostatic action via the bacterial ribosome in contrast to the action of cephalosporins on bacterial cell wall synthesis. Administration of gentamicin is limited to either the intravenous or intramuscular routes, and the optimal dose for uncomplicated genital infections is not known. However, a single intramuscular injection of antibiotic lends itself to outpatient management and may 
reduce the risk of vestibular and renal toxicity that is seen with extended high trough drug concentrations.

In view of concerns about decreasing sensitivity of $N$. gonorrhoeae to current first-line agents, there is a clear need to identify treatment options. This systematic review assesses the clinical effectiveness and safety of gentamicin for the treatment of N. gonorrhoeae.

\section{Methods}

The review protocol was registered with PROSPERO (CRD42012002490) [30].

\section{Criteria for considering studies for the review Types of study}

Randomised controlled trials, quasi-randomised trials and prospective studies with concurrent controls and consistent treatment assignment were eligible for inclusion. Studies with historical controls, before and after studies, case series and case reports were excluded.

\section{Types of participants}

Studies recruiting men and women aged 16 years or over receiving their first antibiotics as an inpatient or outpatient for a microbiological diagnosis of gonorrhoea at any anatomical site were included. Gonorrhoea was diagnosed by microscopy, culture or nucleic acid amplification tests.

\section{Types of intervention}

Studies in which gentamicin was given at any single dose intramuscularly or intravenously were eligible for inclusion. To enable assessment of gentamicin efficacy, studies in which gentamicin was given as part of a combined antibiotic regimen were excluded. Comparators included no treatment, placebo or any alternative antibiotic given either orally or parenterally.

\section{Types of outcome}

Primary outcome The primary outcome is microbiological cure of N. gonorrhoeae (negative microscopy, culture or nucleic acid amplification test).

Secondary outcomes The secondary outcomes are the following:

- Clinical resolution of symptoms (dysuria, genital discharge, genital pain or abdominal pain).

- Need for additional antibiotic therapy.

- Adverse events (rash, allergy, injection site discomfort, renal dysfunction, hearing loss, vestibular dysfunction, other reported adverse events attributed to antibiotic).

- Hospital attendance (admission to hospital, unscheduled clinic attendance).

\section{Search strategy for identification of studies Electronic searches}

A search strategy was developed and used to identify relevant studies (Additional file 1). Databases were searched on 11th May 2012 and 27th July 2012 and updated on 2nd June 2014 as follows: MEDLINE from PubMed 1950 to present, Embase 1980 to present, CINAHL 1981 to present, CAB Abstracts, EThOS and the Cochrane Central Register of Controlled Trials. Searches were repeated of www.clinicaltrials.gov and www.who.int/trialsearch to identify ongoing trials. Papers published in peer-reviewed journals, theses, conference abstracts and reports were included. No language restriction was placed on the search strategy.

\section{Searching other resources}

Searches were repeated in grey literature to identify any unpublished and ongoing research (Additional file 1). References from included studies were reviewed for further relevant studies.

\section{Data collection and analysis Study selection}

Two reviewers (DD and EH) independently screened titles and abstracts against the inclusion criteria to identify eligible citations. Disagreements were resolved by discussion. Full-text copies were obtained if insufficient information was available and of all studies meeting inclusion criteria.

\section{Data extraction}

A standardised data extraction form was developed and utilised. Data were independently extracted from the studies, and discrepancies were resolved by discussion and consultation with a third reviewer if necessary.

\section{Assessment of risk of bias}

Risk of bias in studies was assessed using the risk of bias tool described in the Cochrane Handbook for Systematic Reviews of Interventions [31]. A bias judgement (low risk of bias, high risk of bias or unclear risk of bias) was allocated to each of six domains (sequence generation, allocation of sequence concealment, blinding, incomplete outcome data, selective reporting bias and other bias) within the tool. The tool was developed for assessment of randomised trials, and the Good Research for Comparative Effectiveness (GRACE) checklist, which has been utilised to rate the quality of observational studies of comparative effectiveness, was used to assess non-randomised studies included for data analysis [32].

\section{Data synthesis}

Characteristics, main findings and risk of bias assessment were tabulated for each study. Levels of attrition were noted for included studies. If data were adequate 
for meta-analysis, we planned that results be presented as a summary risk ratio with $95 \%$ confidence intervals, on an intention-to-treat basis.

Reviewing the studies identified a high level of clinical heterogeneity. The dose of gentamicin varied from 160 to $280 \mathrm{mg}$, and the primary assessment of cure was based on symptoms, microscopy and culture or was not reported. The definition and assessment of risk of reinfection was not reported in some studies [33-35], and those with potential re-exposure were excluded in one study [36]. Meta-analysis was considered to be inappropriate due to these methodological differences and the results summarised in a tabular format.

\section{Results}

Eight hundred and thirty-nine studies were identified by the search strategy (Figure 1). Two reviewers independently screened all titles and available abstracts. Nineteen studies were discussed due to disagreement, of which 17 were excluded, as they did not meet pre-specified inclusion criteria. Seventeen full-text articles were retrieved and 12 were excluded after further review.

Five studies with a total of 1,063 participants were included in the review: three randomised trials [28,33,34], one quasi-randomised trial [36] and one non-randomised study with a comparator arm [35].

\section{Description of studies}

Table 1 summarises the characteristics of the included studies. All five studies included men with uncomplicated gonococcal urethritis diagnosed by culture [34], identification of gram-negative diplococci on urethral smear [36] or a combination of Gram-stained urethral smear and culture $[28,34,36]$. Five hundred and twentynine men received intramuscular gentamicin in a single dose $-160 \mathrm{mg}(n=20), 240 \mathrm{mg}(n=207)$ or $280 \mathrm{mg}(n=$ 302). No study compared gentamicin to placebo and comparator antibiotics included an alternative aminoglycoside (kanamycin and spectinomycin) or antibiotic used in the syndromic management of male urethritis.

\section{Assessment of risk of bias}

The included studies were assessed for risk of bias using either the Cochrane risk of bias tool (randomised studies) or the GRACE checklist (observational studies). Study methodology was poorly reported, so that consistently assessing methodological quality and risk of bias in each individual study was difficult. Insufficient detail was often included in the publication to distinguish accurately what was done in contrast to what was reported. As such, risk of bias within and across individual studies was unclear or judged by reviewers to be high (Additional file 2).

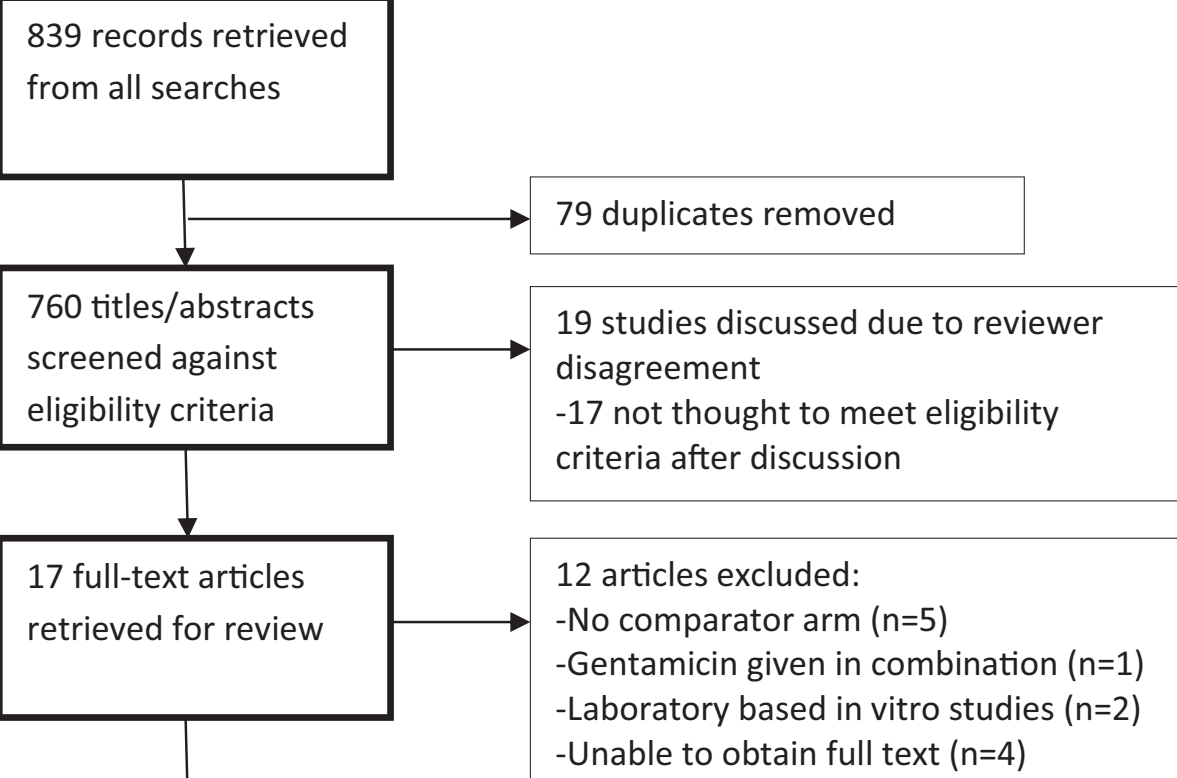

5 studies included in

quantitative analysis

Figure 1 Review profile. 


\begin{tabular}{|c|c|c|c|c|c|c|}
\hline \multirow[t]{2}{*}{ Author } & \multirow[t]{2}{*}{ Methods } & \multirow[t]{2}{*}{ Participants } & \multicolumn{2}{|l|}{ Intervention } & \multirow[t]{2}{*}{ Primary outcome } & \multirow[t]{2}{*}{ Evaluation of re-infection } \\
\hline & & & Gentamicin & Comparator & & \\
\hline \multirow[t]{2}{*}{$\begin{array}{l}\text { Hira et al. } \\
\text { (1984) [36] }\end{array}$} & \multirow{2}{*}{$\begin{array}{l}\text { Quasi-random } \\
\text { (treatment assigned } \\
\text { to alternate } \\
\text { consecutive patients) }\end{array}$} & \multirow{2}{*}{$\begin{array}{l}\text { Men with uncomplicated } \\
\text { gonorrhoea infection } \\
\text { (gram-negative diplococci } \\
\text { on urethral smear), Lusaka, } \\
\text { Zambia }\end{array}$} & \multirow{2}{*}{$\begin{array}{l}\text { Single-dose } \\
\text { gentamicin } 280 \mathrm{mg} \\
\text { intramuscular } \\
\text { injection }(n=302)\end{array}$} & \multirow[t]{2}{*}{$\begin{array}{l}\text { Single-dose kanamycin } 2 \mathrm{~g} \\
\text { intramuscular injection }(n=113)\end{array}$} & Cure & $\begin{array}{l}\text { All patients advised to abstain } \\
\text { from sexual activity for } 2 \text { weeks } \\
\text { after therapy. }\end{array}$ \\
\hline & & & & & $\begin{array}{l}\text { Patients in whom } N \text {. gonorrhoea } \\
\text { persisted or re-appeared (as } \\
\text { determined by a positive result of } \\
\text { a smear or culture) in the absence } \\
\text { of sexual activity during the } \\
\text { follow-up period were considered } \\
\text { to be treatment failure }\end{array}$ & $\begin{array}{l}\text { Patients excluded if reported sexual } \\
\text { activity during } 2 \text { weeks follow-up } \\
\text { period with or without persistent } \\
\text { or re-appearing gonorrhoea on } \\
\text { culture }\end{array}$ \\
\hline \multirow[t]{2}{*}{$\begin{array}{l}\text { Iskandar et al. } \\
\text { (1978) [33] }\end{array}$} & \multirow{2}{*}{$\begin{array}{l}\text { RCT (randomly } \\
\text { allocated to } 3 \\
\text { groups of } 30 \\
\text { patients) }\end{array}$} & \multirow{2}{*}{$\begin{array}{l}\text { Men with acute } \\
\text { gonorrhoea infection } \\
\text { (gonorrhoea on Gram stain } \\
\text { of urethral smears), Egypt }\end{array}$} & \multirow{2}{*}{$\begin{array}{l}\text { Single-dose } \\
\text { gentamicin } 240 \mathrm{mg} \\
\text { intramuscular } \\
\text { injection }(n=30)\end{array}$} & \multirow{2}{*}{$\begin{array}{l}\text { Co-trimoxazole (Bactrim, } \\
\text { Roche) } 8 \text { tablets daily divided } \\
\text { into } 2 \text { doses for } 2 \text { days }(n=30) \text {. } \\
\text { Trimethoprim-sulphametrol } \\
\text { (Lidaprim, Ciba) } 8 \text { tablets } \\
\text { divided into } 2 \text { doses for } 2 \text { days } \\
(n=30)\end{array}$} & Cure & $\begin{array}{l}\text { One case of re-infection reported } \\
\text { in which there was a history of } \\
\text { re-exposure. }\end{array}$ \\
\hline & & & & & $\begin{array}{l}\text { Cases with negative smears plus } \\
\text { resolution of discharge on day } 7 \\
\text { were considered cured }\end{array}$ & $\begin{array}{l}\text { Safe sex advice and assessment } \\
\text { of re-infection not described }\end{array}$ \\
\hline \multirow{2}{*}{$\begin{array}{l}\text { Pareek and } \\
\text { Chowdhury } \\
\text { (1981) [35] }\end{array}$} & \multirow{2}{*}{$\begin{array}{l}\text { Non-randomised, } \\
\text { comparator study }\end{array}$} & \multirow{2}{*}{$\begin{array}{l}\text { Men with urethral } \\
\text { gonorrhoea infection } \\
\text { (culture positive and beta } \\
\text { lactamase detected), } \\
\text { Riyadh, Saudi Arabia }\end{array}$} & \multirow{2}{*}{$\begin{array}{l}\text { Single-dose } \\
\text { gentamicin } 160 \mathrm{mg} \\
\text { intramuscular } \\
\text { injection }(n=20)\end{array}$} & \multirow{2}{*}{$\begin{array}{l}\text { Single-dose spectinomycin } \\
2 \mathrm{~g} \text { intramuscular injection } \\
(n=20)\end{array}$} & Cure & \multirow{2}{*}{$\begin{array}{l}\text { Safe sex advice, definition and } \\
\text { assessment of re-infection not } \\
\text { described }\end{array}$} \\
\hline & & & & & $\begin{array}{l}\text { Patients in whom culture on } \\
\text { days } 3,7 \text { and } 14 \text { post treatment } \\
\text { were negative were considered } \\
\text { cured }\end{array}$ & \\
\hline \multirow{2}{*}{$\begin{array}{l}\text { Yoon et al. } \\
\text { (1988) [34] }\end{array}$} & \multirow{2}{*}{$\begin{array}{l}\text { RCT (random } \\
\text { numbered tickets } \\
\text { used to divide } \\
\text { patients into } \\
2 \text { groups) }\end{array}$} & \multirow{2}{*}{$\begin{array}{l}\text { Men with uncomplicated } \\
\text { gonococcal urethritis (Gram } \\
\text { stain and 'bacteriological } \\
\text { test of urethral secretions'), } \\
\text { Seoul, Korea }\end{array}$} & \multirow{2}{*}{$\begin{array}{l}\text { Single-dose } \\
\text { gentamicin } 240 \mathrm{mg} \\
\text { intramuscular } \\
\text { injection }(n=137)\end{array}$} & \multirow{2}{*}{$\begin{array}{l}\text { Single-dose kanamycin } 2 \mathrm{~g} \\
\text { intramuscular injection } \\
(n=137)\end{array}$} & Cure & \multirow{2}{*}{$\begin{array}{l}\text { All patients advised to avoid } \\
\text { sexual intercourse during the } \\
\text { period of treatment. Definition } \\
\text { and assessment of re-infection } \\
\text { not described }\end{array}$} \\
\hline & & & & & $\begin{array}{l}\text { Cases with negative Gram stain } \\
\text { and bacteriological test } \\
\text { (undefined) of urethral secretions }\end{array}$ & \\
\hline \multirow[t]{4}{*}{$\begin{array}{l}\text { Lule et al. } \\
\text { (1994) [28] }\end{array}$} & \multirow[t]{4}{*}{$\begin{array}{l}\mathrm{RCT} \text { (computerised } \\
\text { randomisation) }\end{array}$} & \multirow{4}{*}{$\begin{array}{l}\text { Men presenting with urethral } \\
\text { discharge }+ \text {-dysuria and } \\
\text { gram-negative intracellular } \\
\text { diplococci on urethral smear } \\
\text { and/or positive } \\
\text { culture, Malawi }\end{array}$} & \multirow[t]{4}{*}{$\begin{array}{l}\text { Single-dose } \\
\text { gentamicin } 240 \mathrm{mg} \\
\text { intramuscular } \\
\text { injection }(n=40)\end{array}$} & $\begin{array}{l}\text { Amoxicillin } 3 \mathrm{gm} \text {, probenecid } \\
1 \mathrm{gm} \text {, and clavulanate } \\
125 \mathrm{mg} \text { by mouth once } \\
(n=60)\end{array}$ & $\begin{array}{l}\text { To determine the relative } \\
\text { contribution of gonorrhoea and } \\
\text { chlamydia to urethritis in Malawi }\end{array}$ & Safe sex advice not described \\
\hline & & & & $\begin{array}{l}\text { Amoxicillin } 3 \mathrm{gm} \text {, probenecid } \\
1 \mathrm{gm} \text {, and clavulanate } \\
125 \mathrm{mg} \text {, by mouth once and } \\
\text { doxycycline } 100 \mathrm{mg} \text { BD for } \\
7 \text { days }(n=56)\end{array}$ & $\begin{array}{l}\text { To evaluate the effectiveness of } \\
\text { five antibiotic therapies for } \\
\text { urethritis }\end{array}$ & \multirow{3}{*}{$\begin{array}{l}6 / 48(12.5 \%) \text { patients with } \\
\text { persistent gonococcal infection } \\
\text { at follow-up reported having sex } \\
\text { between initial and follow-up } \\
\text { visits compared to } 21 \text { of } 249 \\
\text { ( } 8.4 \%) \text { men for whom gonococcal } \\
\text { infection was not detected at } \\
\text { follow-up }(p=0.4)\end{array}$} \\
\hline & & & & $\begin{array}{l}\text { Ciprofloxacin } 250 \mathrm{mg} \text { by } \\
\text { mouth once }(n=59)\end{array}$ & \multirow{2}{*}{$\begin{array}{l}\text { Cure not defined. An assessment } \\
\text { of symptoms and signs, urethral } \\
\text { Gram stain and culture were } \\
\text { obtained at 8-10 days post } \\
\text { treatment }\end{array}$} & \\
\hline & & & & $\begin{array}{l}\text { Co-trimoxazole (trimethoprim } \\
320 \mathrm{mg} / \mathrm{sulphamethoxazole} \\
1,600 \mathrm{mg} \text { ) by mouth for } \\
2 \text { days }(n=29)\end{array}$ & & \\
\hline
\end{tabular}


Table 2 Outcome data of included studies

\begin{tabular}{|c|c|c|c|c|c|}
\hline Outcome & Hira et al. [36] & Iskandar et al. [33] & Pareek and Chowdhury [35] & Yoon et al. [34] & Lule et al. [28] \\
\hline \multirow[t]{7}{*}{ Cure } & Gentamicin: 98\% (216/220) & Gentamicin: 27/30 (90\%) & Gentamicin: 19/20 (95\%) & Gentamicin: 78/125 (62.4\%) & Gentamicin: 38/40 (95\%) \\
\hline & \multirow[t]{6}{*}{ Kanamycin: 95\% (85/89) } & Co-trimoxazole: 29/30 (96.6\%) & Spectinomycin: 16/20 (80\%) & Kanamycin: 86/126 (68.3\%) & Ciprofloxacin: 55/59 (93\%) \\
\hline & & Lidaprim: 29/30 (96.6\%) & & \multirow{5}{*}{$\begin{array}{l}23 \text { patients did not } \\
\text { attend follow-up and were } \\
\text { excluded }\end{array}$} & APC: $40 / 60(67 \%)$ \\
\hline & & $\begin{array}{l}\text { Adjusted to include only } \\
\text { those attending on day } 7 \text { : }\end{array}$ & & & APC-D: 52/56 (93\%) \\
\hline & & Gentamicin: 19/22 (86.4\%) & & & \multirow[t]{3}{*}{ Co-trimoxazole: 14/29 (48\%) } \\
\hline & & Bactrim: 15/16 (93.7\%) & & & \\
\hline & & Lidaprim: 20/21(95.2\%) & & & \\
\hline Need for additional treatment & No data & No data & No data & No data & No data \\
\hline Adverse event & $\begin{array}{l}\text { 'No serious toxicity or other adverse } \\
\text { reactions were noticed in either group } \\
\text { of men. Serum creatinine values were } \\
\text { normal in the } 52 \text { patients given } \\
\text { gentamicin and the } 28 \text { kanamycin } \\
\text { whose blood samples were tested' }\end{array}$ & $\begin{array}{l}\text { 'No adverse side effects } \\
\text { were observed in any } \\
\text { of the patients' }\end{array}$ & $\begin{array}{l}\text { There were no obvious side } \\
\text { effects with either of these } \\
\text { drugs. The blood urea and } \\
\text { creatinine values remained } \\
\text { within normal limits' }\end{array}$ & $\begin{array}{l}\text { There was no side effect } \\
\text { of using kanamycin and } \\
\text { gentamicin' }\end{array}$ & No data \\
\hline Hospital attendance & No data & No data & No data & No data & No data \\
\hline
\end{tabular}




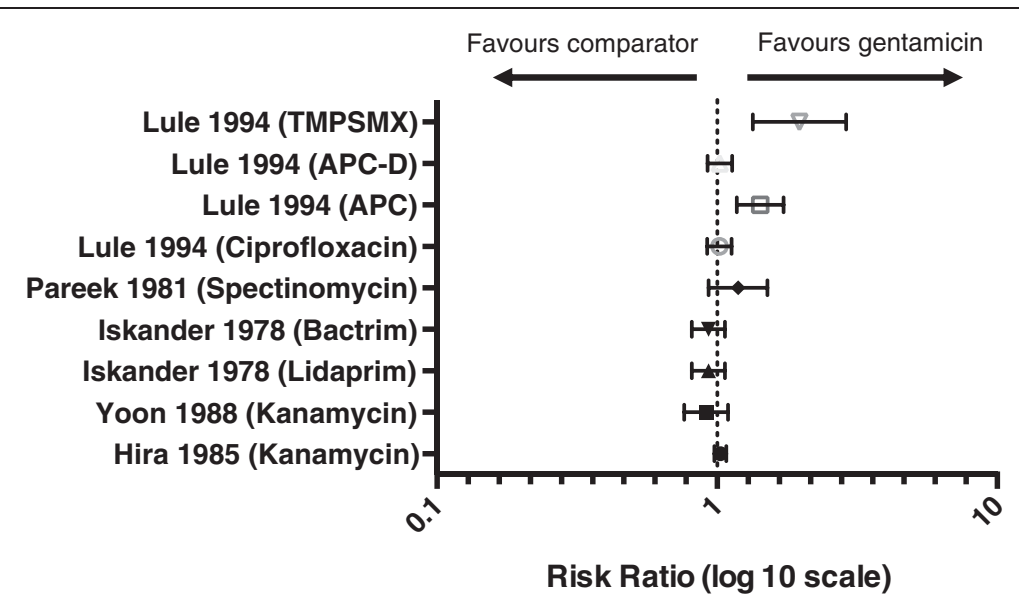

Figure 2 Efficacy of gentamicin. The probability of cure following treatment with gentamicin compared to cure with a comparator antibiotic. The probability of cure was comparable between gentamicin and comparator antibiotics. TMPSMX trimethoprim/sulphamethoxazole, APC amoxicillin, probenecid and clavunate, APC-D amoxicillin, probenecid, clavunate and doxycycline. Risk ratios: Lule (TMPSMX) 1.9679 (95\% Cl 1.3412-2.8873); Lule (APC-D) 1.0231 (95\%Cl 0.924201.1325); Lule (APC) 1.4250 (95\% Cl 1.1754-1.7275); Lule (ciprofloxacin) 1.0191 (95\% Cl 0.9231-1.1251); Pareek (specinomycin) 1.1875 (95\% Cl 0.9331-1.5113); Iskander (Bactrim) 0.9310 (95\% Cl 0.8122-1.0672); Iskander (Lidaprim) 0.9310 (95\% Cl 0.8122-1.0672); Yoon (kanamycin) 0.9142 (95\% Cl 0.7630-1.0954); Hira (kanamycin) 1.0280 (95\% Cl 0.979301.0791).

\section{Effectiveness of gentamicin}

All five studies reported cure, as defined in Table 1, as a primary outcome (Table 2). Fixed effects meta-analysis was not performed for any of the defined outcomes due to the high level of clinical heterogeneity between studies and the high risk of bias within individual studies (Additional file 2). Whilst cure, presented as a percentage rate, was reported in each of the included studies, they differed significantly in definition of cure (clinical cure or negative microscopy and/or culture), timing of cure and their assessment of re-infection (Additional file 3).

Figure 2 summarises the efficacy of gentamicin in the treatment of uncomplicated gonorrhoea infection. The probability of cure was comparable between gentamicin and comparator antibiotics.

\section{Discussion}

Our systematic review found insufficient data to support or refute the role of gentamicin in the treatment of gonorrhoea infections. Five studies of single-dose intramuscular gentamicin for the treatment of uncomplicated gonococcal urethritis in men met inclusion criteria and reported cure rates of $62 \%$ to $98 \%$. The probability of cure was comparable between gentamicin and comparator antibiotics.

A separate systematic review assessing the effectiveness of gentamicin for uncomplicated urogenital gonorrhoea infection has recently been published [37] and reported a pooled percentage with negative culture after single-dose gentamicin of $91.5 \%$ (95\% CI $88 \%$ to $94 \%$ ). It included three studies of which only two met our inclusion criteria due to methodological differences [36]. Firstly, Dowell and Kirkcaldy included studies with historical controls and single-arm case series. Secondly, they included studies in which gentamicin was given as part of a treatment regimen in combination with other antibiotics. Thirdly, their definition of gonorrhoea was limited to participants with uncomplicated urogenital infection and diagnosis was restricted to urethral or cervical culture at the time of treatment and follow-up.

Our data supports the conclusion that gentamicin may not achieve the $95 \%$ cure rate recommended by the World Health Organization for empirical therapy. However, the risk of bias within available studies limits any firm conclusions being drawn and a potential role for gentamicin as an alternative or adjunctive agent remains and merits evaluation in randomised trials. Preliminary data from an American study examining the effectiveness of gentamicin with azithromycin recently suggested high efficacy (202/ 202 negative culture at $10-17$ days post treatment) but poor tolerability of this regimen $(27.7 \%$ reporting nausea and $47 \%$ any gastrointestinal disturbance) [38]. Also, this study did not determine the efficacy of the individual antibiotics, or efficacy of gentamicin for extra-genital infections, and further randomised control trials incorporating currently recommended antibiotic regimens, comparing different gentamicin doses and correlating in vitro gentamicin susceptibilities to clinical response are needed.

A comprehensive review of the literature was performed with all relevant identified articles obtained and translated. Few studies met the inclusion criteria with limited numbers of patients receiving single-dose intramuscular gentamicin. The five studies included for data extraction were performed in Malawi, Zambia, Egypt, Korea and Saudi Arabia, and their findings may not be applicable to other settings where first-line treatment regimens and gentamicin susceptibility may differ. No studies of genital infection in women or non-genital gonorrhoea 
infection were identified by the search strategy, and the findings cannot be extrapolated to these groups.

\section{Quality of included studies}

Two of the identified studies were very small with 20 [35] and 30 [33] patients receiving gentamicin. The comparator antibiotic varied across the included studies, and all were suboptimal when compared to current UK management guidelines. Two studies were described as randomised control trials, but none adequately described their method of generating a random allocation sequence, method of concealment or blinding to the allocation schedule. In addition, differences in definition of gonococcal infection, gentamicin dosing, comparator antibiotic, evaluation of re-infection and definition and timing of cure meant that it was inappropriate to pool data for meta-analysis.

\section{Conclusions}

Based on current evidence, there are insufficient data to support or reject a recommendation for inclusion of singledose gentamicin as a first-line agent in the treatment of uncomplicated gonorrhoea infection. Further high-quality RCTs incorporating currently recommended antibiotic regimens with laboratory measurement of gentamicin MIC are needed to inform a change in clinical practice.

\section{Additional files}

Additional file 1: Search strategy. Search strategy used to identify

studies for inclusion in the review.

Additional file 2: Risk of bias assessment. Summary of the risk of bias in each included study.

Additional file 3: PRISMA statement. Checklist against PRISMA guidelines for the reporting of systematic reviews.

\section{Competing interests}

The authors declare that they have no competing interests.

\section{Authors' contributions}

$\mathrm{EH}$ and DD conducted the review and writing of the manuscript. LD reviewed the protocol, gave statistical advice and reviewed the manuscript. JDCR contributed to the initial concept and reviewed and revised the manuscript. All authors read and approved the final manuscript.

\section{Author details}

${ }^{1}$ Whittall Street Clinic, University Hospitals Birmingham, Birmingham B6 4DH, UK. ${ }^{2}$ Nottingham Clinical Trials Unit, Nottingham Health Science Partners, Queen's Medical Centre, Nottingham, UK.

Received: 10 June 2014 Accepted: 8 September 2014 Published: 19 September 2014

\section{References}

1. Health Protection England: Sexually transmitted infections and chlamydia screening in England 2012. Health Prot Rep 2013, 7(23):8-21.

2. World Health Organization: Global incidence and prevalence of selected curable sexually transmitted infections, 2008. [http://www.who.int/ reproductivehealth/publications/rtis/stisestimates/en/]

3. Aghaizu A, Adams EJ, Turner K, Kerry S, Hay P, Simms I, Oakeshott P: What is the cost of pelvic inflammatory disease and how much could be prevented by screening for Chlamydia trachomatis? Cost analysis of the Prevention of Pelvic Infection (POPI) trial. Sex Transm Infect 2011, 87(4):312-317.

4. Yeh JM, Hook EW, Goldie SJ: A refined estimate of the average lifetime cost of pelvic inflammatory disease. Sex Transm Dis 2003, 30(5):369-378.

5. Venkatesh KK, van der Straten A, Cheng H, Cheng H, Montgomery ET, Lurie MN, Chipato T, Ramjee G, Blanchard K, Padian NS, Mayer KH, de Bruyn G: The relative contribution of viral and bacterial sexually transmitted infections on HIV acquisition in southern African women in the methods for improving reproductive health in Africa study. Int J STD AIDS 2011, 22(4):218-224.

6. Watson-Jones D, Baisley K, Weiss HA, Tanton C, Changalucha J, Everett D, Chirwa T, Ross D, Clayton T, Hayes R: Risk factors for HIV incidence in women participating in an HSV suppressive treatment trial in Tanzania. AIDS 2009, 23(3):415-422.

7. Pathela P, Braunstein S, Blank S, Schillinger J: HIV incidence and time to diagnosis among men with bacterial rectal infections, New York City. Sex Transm Infect 2011, 87(Suppl 1):A184.

8. Cohen MS, Hoffman IF, Royce RA, Kazembe P, Dyer JR, Daly CC, Zimba D, Vernazza PL, Maida M, Fiscus SA, Eron JJ Jr: Reduction of concentration of HIV-1 in semen after treatment of urethritis: implications for prevention of sexual transmission of HIV-1: AIDSCAP Malawi Research Group. Lancet 1997, 349(9069):1868-1873.

9. Ghys PD, Fransen K, Diallo MO, Ettiègne-Traoré V, Coulibaly IM, Yeboué KM Kalish ML, Maurice C, Whitaker JP, Greenberg AE, Laga M: The associations between cervicovaginal HIV shedding, sexually transmitted diseases and immunosuppression in female sex workers in Abidjan. Cote d'lvoire AIDS 1997, 11(12):F85-F93.

10. Levine WC, Pope V, Bhoomkar A, Tambe P, Lewis JS, Zaidi AA, Farshy CE, Mitchell S, Talkington DF: Increase in endocervical CD4 lymphocytes among women with nonulcerative sexually transmitted diseases. $J$ Infect Dis 1998, 177(1):167-174.

11. HPA Guidance for gonorrhoea testing in England and Wales, 2010. [http://www.bashh.org/BASHH/Guidelines/Guidelines/BASHH/Guidelines/ Guidelines.aspx]

12. Bignell C: European (IUSTI/WHO) guideline on the diagnosis and treatment of gonorrhoea in adults. Int J STD AIDS 2009, 20(7):453-457.

13. Smith DW, Tapsall JW, Lum J: Guidelines for the use and interpretation of nucleic acid detection tests for Neisseria gonorrhoea in Australia: a position paper on behalf of the Public Health Laboratory Network. [http://www.health.gov.au/internet/main/publishing.nsf/Content/cdacdi2904-pdf-cnt.htm/\$FILE/cdi2904b.pdf]

14. CDC Sexually Transmitted Diseases Guidelines, 2010: gonococcal infections. [http://www.cdc.gov/std/treatment/2010/gonococcal-infections.htm]

15. World Health Organization: Guidelines for the management of sexually transmitted diseases. [http://www.who.int/hiv/pub/sti/en/ STIGuidelines2003.pdf]

16. Bignell C, FitxGerald M: UK national guideline for the management of gonorrhoea in adults, 2011. [http://www.bashh.org/BASHH/Guidelines/ Guidelines/BASHH/Guidelines/Guidelines.aspx]

17. Government of South Australia, Communicable Disease Control Branch: Revision of treatment guidelines for uncomplicated gonorrhoea. [http://www.health.wa.gov.au/diseasewatch/vol17_issue3/gonorrhoeaetreatment.cfm]

18. European Centre for Disease Prevention and Control: Response plan to control and manage the threat of multi-drug resistant gonorrhoea in Europe. [http://www.ecdc.europa.eu/en/publications/Publications/1206ECDC-MDR-gonorrhoea-response-plan.pdf]

19. HPA GRASP 2010 Report. [http://webarchive.nationalarchives.gov.uk/ 20140714084352/http://www.hpa.org.uk/webc/HPAwebFile/HPAweb_C/ 1316016752917]

20. CDC 2010 STD Surveillance Report: Gonorrhoea. [http://www.cdc.gov/std/ stats10/gonorrhea.htm]

21. Ohnishi M, Golparian D, Shimuta K, Saika T, Hoshina S, Iwasaku K, Nakayama S, Kitawaki J, Unemo M: Is Neisseria gonorrhoeae initiating a future era of untreatable gonorrhea?: detailed characterization of the first strain with high-level resistance to ceftriaxone. Antimicrob Agents Chemother 2011, 55(7):3538-3545.

22. Unemo M, Golparian D, Nicholas R, Ohnishi M, Gallay A, Sednaoui P: High-level cefixime- and ceftriaxone-resistant Neisseria gonorrhoeae in Europe (France): novel penA mosaic allele in a successful international clone causes treatment failure. Antimicrob Agents Chemother 2012, 56(3):1273-1280. 
23. Carnicer-Pont D, Smithson A, Fina-Homar E, Bastida MT: First cases of Neisseria gonorrhoeae resistant to ceftriaxone in Catalonia, Spain, May 2011. Enferm Infecc Microbiol Clin 2012, 30(4):218-219.

24. Ameyama S, Onodera S, Takahata M, Minami S, Maki N, Endo K, Goto H, Suzuki H, Oishi Y: Mosaic-like structure of penicillin-binding protein 2 gene (penA) in clinical isolates of Neisseria gonorrhoeae with reduced susceptibility to cefixime. Antimicrob Agents Chemother 2002, 46(12):3744-3749.

25. Ito M, Deguchi T, Mizutani KS, Yasuda M, Yokoi S, Ito S, Takahashi Y, Ishihara S, Kawamura Y, Ezaki T: Emergence and spread of Neisseria gonorrhoeae clinical isolates harboring mosaic-like structure of penicillin-binding protein 2 in Central Japan. Antimicrob Agents Chemother 2005, 49(1):137-143.

26. Tanaka M, Nakayama H, Huruya K, Konomi I, Irie S, Kanayama A, Saika T, Kobayashi I: Analysis of mutations within multiple genes associated with resistance in a clinical isolate of Neisseria gonorrhoeae with reduced ceftriaxone susceptibility that shows a multidrug-resistant phenotype. Int J Antimicrob Agents 2006, 27(1):20-26.

27. Brown LB, Krysiak R, Kamanga G, Mapanje C, Kanyamula H, Banda B, Mhango C, Hoffman M, Kamwendo D, Hobbs M, Hosseinipour MC, Martinson F, Cohen MS, Hoffman IF: Neisseria gonorrhoeae antimicrobial susceptibility in Lilongwe, Malawi, 2007. Sex Transm Dis 2010, 37:169-172.

28. Lule G, Behets FM, Hoffman IF, Dallabetta G, Hamilton HA, Moeng S, Liomba G, Cohen MS: STD/HIV control in Malawi and the search for affordable and effective urethritis therapy: a first field evaluation. Genitourin Med 1994, 70(6):384-388.

29. Chisholm SA, Quaye N, Cole MJ, Fredlund H, Hoffmann S, Jensen JS, van de Laar MJ, Unemo M, Ison CA: An evaluation of gentamicin susceptibility of Neisseria gonorrhoeae isolates in Europe. J Antimicrob Chemother 2011, 66(3):592-595

30. Hathorn E, Dhasmana D, Dule L, Ross J, Harding J: The effectiveness of gentamicin in the treatment of Neisseria gonorrhoeae: a systematic review. PROSPERO: International Prospective Register of Systematic Reviews. 2012: CRD42012002490. [http://www.crd.york.ac.uk/ NIHR_PROSPERO/]

31. The Cochrane Collaboration: Chapter 8: Assessing risk of bias included studies. [http://handbook.cochrane.org/]

32. Dreyer NA, Velentgas $P$, Westrich K, Dubois R: The GRACE checklist for rating the quality of observational studies of comparative effectiveness: a tale of hope and caution. JMCP 2014, 20(3):301-308.

33. Iskandar IO, Nahuib F, Gabry L EL: A comparative study of gentamicin, co-trimoxazole and trimethoprim-sulphametrol in acute gonococcal urethritis. J Egypt Med Assoc 1978, 61:489-495.

34. Yoon JY, Kim YT, Kim JH: Treatment of uncomplicated male gonococcal urethritis: kanamycin vs. gentamicin. Korean J Dermatol 1988, 26(2):184-188.

35. Pareek SS, Chowdhury MNH: Comparative study between gentamicin and spectinomycin in the treatment of infections to penicillin-resistant gonococci. Curr Ther Res 1981, 30(2):177-180.

36. Hira SK, Attili VR, Kamanga J, Mkandawire O, Patel JS, Patel MI: Efficacy of gentamicin and kanamycin in the treatment of uncomplicated gonococcl urethritis in Zambia. Sex Transm Dis 1985, 12(1):52-54

37. Dowell D, Kirkcaldy RD: Effectiveness of gentamicin for gonorrhoea treatment: systematic review and meta-analysis. Sex Transm Inf 2012, 88:589-594.

38. Kirkcaldy RD: Treatment of gonorrhoea in an era of emerging cephalosporin resistance and results of a randomised trial of new potential treatment options. Sex Transm Infect 2013, 89:A14-A15. doi:10.1136/sextrans-2013-051184.0043.

doi:10.1186/2046-4053-3-104

Cite this article as: Hathorn et al:: The effectiveness of gentamicin in the treatment of Neisseria gonorrhoeae: a systematic review. Systematic Reviews 2014 3:104

\section{Submit your next manuscript to BioMed Central and take full advantage of:}

- Convenient online submission

- Thorough peer review

- No space constraints or color figure charges

- Immediate publication on acceptance

- Inclusion in PubMed, CAS, Scopus and Google Scholar

- Research which is freely available for redistribution

Submit your manuscript at www.biomedcentral.com/submit
Ciomed Central 